Er, N., Karademir, E. ve Tezel, Ö. (2021). Ana dilde iletişim yetkinliğine yönelik ölçek geliştirilmesi ve öğretmen adaylarının yetkinlik düzeyleri. Ana Dili Eğitimi Dergisi, 9(3), 670-685.

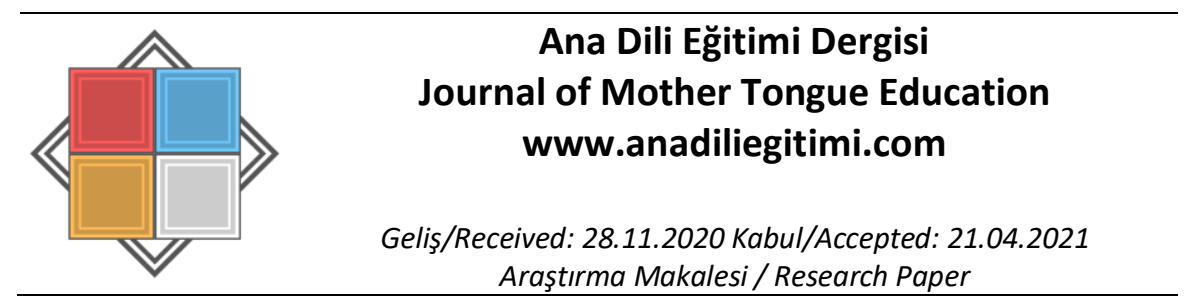

\title{
Ana Dilde İletişim Yetkinliğine Yönelik Ölçek Geliştirilmesi ve Öğretmen Adaylarının Yetkinlik Düzeyleri*
}

\author{
Neslihan $E R^{* *}$ \\ Ersin KARADEMIR ${ }^{* * *}$ \\ Özden TEZEL ${ }^{* * * *}$
}

\begin{abstract}
Öz
Ana dilde iletişim yetkinliğinin kazandırılmasına yönelik çalışmalara, ilkokuldan üniversiteye kadar öğretimin her kademesinde yer verilmelidir. Buradan yola çıkarak bu çalışmada ana dilde iletişim yetkinliğini ölçmeye yarayacak ölçme aracı geliştirmek ve öğretmen adaylarının ana dilde iletişim yetkinliğini belirlemek amaçlanmıştır. Araştırmanın çalışma grubunu 2019-2020 eğitim ve öğretim yılı güz döneminde bir devlet üniversitesinde Fen Bilimleri Öğretmenliği, Matematik Öğretmenliği ve Sınıf Öğretmenliğinde öğrenim görmekte olan 390 öğretmen adayı oluşturmaktadır. Bu çalışmada 22 maddelik "Ana Dilde Illetişim Ölçeği" geliştirilmiştir. Ölçeğin bütününe ilişkin hesaplanan Cronbach's Alpha değeri 0,857 bulunmuştur. Yapılan analiz sonuçları dikkate alındığında, ölçeğin öğretmen adaylarının ana dilde iletişim yetkinliklerini belirlemek amacıyla kullanılabilir bir ölçme aracı olduğu görülmektedir. Öğretmen adaylarının ana dilde iletişim yetkinliği cinsiyet ve sınıf değişkenine göre anlamlı bir fark göstermemiştir. Öğretmen adaylarının STEM eğitimi, argümantasyon eğitimi, okudukları bölüm ve bölümlerinden memnuniyet değişkenlerine göre ana dilde iletişim yetkinliklerinde anlamlı bir fark bulunmuştur. Araştırma sonucunda "Ana Dilde Iletişim Yetkinliği Ölçeği"nin ana dilde iletişim yetkinlik düzeyinin belirlenmesine yönelik geçerli ve güvenilir bir araç olduğu belirlenmiştir.
\end{abstract}

Anahtar Kelimeler: yetkinlik, ana dilde iletişim yetkinliği, ölçek geliştirme

\section{Developing a Scale for Communication Competency in Mother Tongue and Competency Levels of Prospective Teachers}

\begin{abstract}
Studies aimed at gaining communication competence in the mother tongue should be included in all levels of education from primary school to university. Based on this, this study aims to develop a tool to measure communication competence in mother tongue and to determine the communication competence of teacher candidates in mother tongue. The study group consists of 390 teacher candidates who are studying in a state university in the fall semester of the 2019-2020 academic year, at the Faculty of Education, Science Education, Mathematics Teaching and Elementary Education departments. In this study, a 22-item "Communication in the Mother Tongue Scale" was developed. Cronbach's Alpha value calculated for the whole scale was found to be 0,857 . The results of the analysis showed that the scale was a useful measurement tool to determine the communication competencies of pre-service teachers in the mother tongue. In
\end{abstract}

\footnotetext{
${ }^{*}$ Bu makale ESOGÜ-BAP birimi tarafından desteklenen 2020-2803 nolu projeden üretilmiştir.

${ }^{* *}$ Yüksek Lisans Öğrencisi, Eskişehir Osmangazi Üniversitesi, Eğitim Bilimleri Enstitüsü, Matematik ve Fen Bilimleri Eğitimi Anabilim Dalı, Eskişehir, neslihaner26@hotmail.com, ORCID: 0000-0003-0773-3154

*** Doç. Dr., Eskişehir Osmangazi Üniversitesi, Eğitim Fakültesi, Matematik ve Fen Bilimleri Eğitimi Bölümü, Eskişehir, eekarademir@gmail.com ,ORCID: 0000-0002-8519-622X

${ }^{* * * *}$ Prof. Dr., Eskişehir Osmangazi Üniversitesi, Eğitim Fakültesi, Matematik ve Fen Bilimleri Eğitimi Bölümü, Eskişehir, ozden.tezel@gmail.com , ORCID: 0000-0002-9930-7058
} 
terms of gender and grade variables, the communication competence of the teacher candidates in the mother tongue did not show a significant difference. In terms of STEM education, argumentation teaching, departments and contentment with their departments variables, a significant difference was found in the communication competencies of the teacher candidates in the mother tongue. As a result of the study, it was determined that the "Communication Competence in Mother Tongue Scale" was a valid and reliable tool for determining the level of communication competence in the mother tongue.

Keywords: competence, communication competence in mother tongue, scale development

\section{Giriş}

Eğitim, insanlarda tutum ve davranış değişikliği sağlamaktır (Yaman ve Göçen, 2014). Eğitimin amacı: geçmişten günümüze süregelen sosyal ve ulusal değerleri tanıtmak ve bu değerleri yeni nesillere benimsetmek, bugünün gerçeklerini göstermek ve gelecekte bizleri ileri taşıyacak değerler kazandırmak olarak belirtilmektedir. Yani eğitim kısaca: "Dünü tanıtma, bugünü kavratma ve yarına hazırlamadır." şeklinde tanımlanabilir (Kavcar, 1999, s. 1). Millî Eğitim Bakanlığı Türkçe Dersi Öğretim Programı'nda eğitim sisteminin temel amacı: “Değerlerimiz ve yetkinliklerle bütünleşmiş bilgi, beceri ve davranışlara sahip bireyler yetiştirmek." olarak tanımlanmıştır. Öğretim programlarıyla bilgi, beceri ve davranışlar kazandırılırken değerlerimiz ve yetkinlikler bu alanlardaki bütünlüğü sağlamaktadır (MEB, 2019a).

Ulusal Yeterlilik Çerçevesi (UYÇ): bir ülkede geçmişten günümüze varlığını korumuş yeterlilikleri tanımlamak, belirlenmiş olan ölçütlere göre bu yeterlilikleri sınıflandırmak ve bunları farklı ülkelerle karşılaştırmak için kullanılan seviyelere ayrılmış ilkeler ve kurallar bütünüdür (TYÇ, 2015). Türkiye Yeterlilikler Çerçevesi (TYÇ), Avrupa Yeterlilikler Çerçevesi (AYÇ) ile uyumlu şekilde tasarlanmış olan Türkiye'nin ulusal yeterlilik çerçevesidir. TYÇ, eğitim sistemindeki tüm kademeler (ilköğretim, ortaöğretim ve yükseköğretim) dahil genel ve mesleki eğitim ve öğretim programlarındaki tüm yeterlilik esaslarını tanımlamaktadır. Türkiye Yeterlilikler Çerçevesi, sekiz (8) seviyeden oluşacak şekilde tasarlanmıştır. Her seviye, o seviyedeki yeterliliklerin ortak öğrenme kazanımları temel alınarak tanımlanmıştır. Her seviyede bilgi, beceri ve yetkinlikler başlıkları altında seviye tanımlayıcısı olarak adlandırılan öğrenme kazanımlarına ilişkin tanımlar dizisi yer almaktadır. Bu seviye tanımlayıcıları TYÇ'nin temelini oluşturmaktadır (TYÇ, 2015). TYÇ'de yetkinlik; bilgi ve becerilerin bir öğrenme ortamında öğrencinin bireysel veya öğretmen desteği ile kullanması, öğrenme ihtiyaçlarının belirlenmesi ve bu ihtiyaçların karşılanması, sorumlulukların dikkate alınması şeklinde tanımlanmıştır (TYÇ, 2015). Türkiye Yeterlilikler Çerçevesi'nde öğrencilerin ulusal ve uluslararası düzeyde kişisel, sosyal, akademik ve iş hayatlarında ihtiyaç duyacakları yetkinlikler belirlenmiştir. 2018 yılında tüm derslerde öğretim programları güncellenmiş, TYÇ'de tüm öğretim programlarında yer alan sekiz anahtar yetkinlik tanımlanmıştır. TYÇ'de tanımlanan anahtar yetkinlikler: yabancı dillerde iletişim, matematiksel yetkinlik ve bilim/teknolojide temel yetkinlikler, dijital yetkinlik, öğrenmeyi öğrenme, sosyal ve vatandaşlıkla ilgili yetkinlikler, inisiyatif alma ve girişimcilik, kültürel farkındalık ve ifadedir. Bunlardan biri de “Ana Dilde İletişim Yetkinliği”dir (MEB, 2019a).

Dil, TDK (2019) tarafından "İnsanların düşündüklerini ve duyduklarını bildirmek için kelimelerle veya işaretlerle yaptıkları anlaşma, lisan." olarak tanımlanmıştır. Dil; öğrencilerin çevrelerinde gerçekleşen tüm olayları sorgulamasına, karar vermesine, farklı açılardan olayları inceleyerek değerlendirmesine, sosyal ve çağdaş bir birey olmasına büyük katkı sağlamaktadır (Özatalay, 2007). Ana dilde iletişim: kavram, düşünce, görüş, duygu ve olguları hem sözlü hem de yazılı olarak ifade etme ve yorumlama (dinleme, konuşma, okuma ve yazma); eğitim ve öğretim, iş yeri, ev ve eğlence gibi her türlü sosyal ve kültürel bağlamda uygun ve yaratıcı bir şekilde dilsel etkileşimde bulunmaktır (MEB, 2019a, s.4).

Ana dili eğitimi dersi olan Türkçe, tüm derslerin temelini oluşturmaktadır. Öğrenciler, bütün derslerin öğrenme süreçlerinde ana dilleri olan Türkçeyi kullanmaktadırlar. Öğrencilerin okulda ve günlük yaşantılarında başarılı bireyler olmaları ana dillerini doğru ve düzgün bir şekilde öğrenmelerine ve kullanmalarına bağlıdır (Yaman ve Dağtaş, 2015). Hangi ders ya da öğrenme alanı olursa olsun bilgi öğretimi ve beceri kazandırma sürecinin ana dili ile yapılıyor olması hem Türkçenin hem de temel dil 
beceri alanlarının önemini ortaya koymaktadır. Bu sebeple ana dil eğitimi, bir dersin ya da bir eğitim öğretim etkinliğinin ötesinde bir konu haline gelmektedir (Ceran ve Deniz, 2015). Bireyin tüm hayatı boyunca intiyaç duyacağı bilgi ve beceriler ile Türkçe derslerinin kazandırmayı amaçladığı bilgi ve becerilerin birebir örtüştüğünü belirten Sever (2011, s.11): “Ana dili eğitimi, özellikle ilköğretimde bütün derslerin temelini oluşturur. Çünkü ana dilinde yetkinliğe ulaştıkça düşünce yapısı, yorum gücü gelişen, duygu ve beğeni inceliği kazanan, ulusal ve evrensel kültür birikimini algılamaya başlayarak kimliğini geliştiren bir öğrenci öteki dersleri de büyük ölçüde başaracaktır." diyerek Türkçeyi kullanma becerisini tüm derslerin temeline almaktadır. Ana dil eğitimi, öğrencileri iki farkı yönden etkileyebilmektedir. Birincisi, öğrencinin ana dilini doğru ve güzel kullanarak anlatım yeteneğini geliştirmesidir; ikincisi, öğrencinin düşünce olgunluğu kazanarak kişiliği geliştirmesidir (Açık Önkaş, 2010). Türkçe Dersi Öğretim Programı: tüm alanlarda öğrenme, kişisel ve sosyal gelişme ile mesleki becerileri edinmenin ön şartı olarak öğrencilerin hayat boyu kullanabilecekleri dil becerilerini (dinleme/ izleme, konuşma, okuma ve yazma) kazanmaları, bu edindikleri becerileri kullanarak kendilerini birçok yönden geliştirmeleri, etkili iletişim kurmaları, okuma-yazma alışkanlığı kazanmalarını sağlayacak bilgi, beceri ve yeterliliklerinin geliştirilmesini kabul görmektedir (MEB, 2019a).

Okuma alışkanlığı kazanmış, düşünen, çevresine duyarlı bireyler yetiştirmek ana dili eğitiminin genel amacıdır. İlkokula başlanılan andan, üniversiteden mezun olunan ana kadar süren öğretim serüveninin bütün kademeleri arasında bütünlük sağlanmalı, kazandırılan davranışlar kademeli bir şekilde geliştirilmelidir (Açık Önkaş, 2010). Ana dili eğitimi, öğrencilerin diğer dersleri ve günlük hayatları ile doğrudan bağlantılıdır. Öğrencilerin yaşanmışıklarını temel alarak konuşma anında anlama ve anlatma becerilerinin geliştirilmesini amaçlamaktadır. Ana dili dersleri sadece bir ders olarak görülmemelidir. Ana dili dersleri, bireyin yaşamı boyunca ihtiyaç duyacağı dil becerilerinin kazandırılmasını sağlayan bir beceri edinme süreci olarak görülmelidir (Yaman ve Demirtaş, 2013; Akt. Yaman ve Göçen, 2014). Uluslararası Öğrenci Değerlendirme Programı (PISA), Ekonomik İşbirliği ve Kalkınma Örgütü (OECD) tarafından 3 yılda bir düzenlenmektedir. PISA'daki temel amaç, öğrencilerin okulda öğrendikleri bilgi ve becerileri günlük yaşamda kullanma becerisini ölçmektir (MEB, 2018). Türkiye' nin okuma becerileri alanındaki durumu incelendiğinde, katılımcı ülkelerin ortalama puanından daha yüksek ortalama puana sahip olduğu görülmektedir. Türkiye, PISA 2018'e katılan 79 ülke arasında okuma becerileri alanında 40. sırada, 37 OECD ülkesi arasında ise 31. sırada yer almaktadır. Son iki sınavı temel alındığında, Türkiye'nin okuma becerileri ortalama puanı 428'den 466'ya yükselmiştir. Son iki uygulama sonucu arasındaki fark, okuma becerileri alanındaki iyileşmenin önemli bir göstergesidir (MEB, 2019b). PISA gibi uluslararası sınavlarda başarılı olabilmek için öncelikle okuduğunu anlamlandırma becerisinin gelişmesi gerekmektedir. Bu da ana dilini etkili bir şekilde kullanabilmekle mümkündür (Yıldız, 2015).

Ana dilde iletişim yetkinliğinin kazandırılmasına yönelik çalışmalara, ilkokuldan üniversiteye kadar öğretimin her kademesinde yer verilmelidir. Üniversitelerde ana dili derslerinin sevilen, zevkli, verimli bir çalışma alanı haline getirilmesi üniversite mezunlarının ana dilinin kullanma becerilerini olumlu yönde etkileyecektir. Bu doğrultuda ana dilinin etkinlik alanlarına dikkat edilerek yapılan eğitimöğretimle öğrencilerin kelime hazinelerinin arttı̆̆ı, daha eleştirel, yoruma yönelik ve sentez düzeyinde kavramalara yaklaştıkları gözlemlenmiştir (Açık Önkaş, 2010). Anlamaya ve anlatmaya dayalı etkinliklerle etkileşimin sağlandığı öğretim ortamları, öğrencilerin yeni deneyimler kazanmasını sağlar (Sever, 2001). Anlama ve anlatma etkinliklerinin işlevselliği; düşüncenin oluşmasına, gelişmesine ve paylaşılmasına olanak tanır. Düşünce üretme ve tartışma etkinlikleriyle sürekli beslenen ve zenginleşen eğitim ortamları, dilin etkili bir iletişim aracı olmasına kaynaklık eder. Üniversitelerde ana dili eğitimi; öğrencilerin dili kullanma becerisi, dil bilinci, dil duyarlılığı ve yaratıcıı̆ı̆ı ortaya çıkarmalıdır (Açık Önkaş, 2010). Buradan yola çıkarak bu çalışmada ana dilde iletişim yetkinliğini ölçmeye yarayacak ölçme aracı geliştirmek ve öğretmen adaylarının ana dilde iletişim yetkinliğini belirlemek amaçlanmıştır. 


\section{Araştırmanın Modeli}

\section{Yöntem}

Bu çalışmada nicel araştırma yöntemi kullanılmıştır. Nicel araştırma yöntemlerinden tarama modeli uygulanmıştır. Tarama modeli, geçmişte ya da günümüzde var olan bir durumu olduğu şekliyle tespit etmeyi amaçlayan bir araştırma modelidir. Olay, birey ya da nesne kendi koşulları içinde araştırılır ve olduğu gibi tanımlanmaya çalışılır (Karasar, 2016).

\section{Araştırma grubu}

Araştırmanın çalışma grubunu, 2019-2020 eğitim ve öğretim yılı güz döneminde eğitim fakültesinde öğrenim görmekte olan 390 öğretmen adayı oluşturmaktadır. Fen Bilimleri Öğretmenliği, Matematik Öğretmenliği ve Sınıf Öğretmenliği bölümlerinde öğrenimlerine devam eden çalışma grubunun demografik bilgileri Tablo 1'de verilmiştir.

Tablo 1.

Çalışma Grubunun Demografik Özellikleri

\begin{tabular}{|c|c|c|c|}
\hline & Katılımcılar & $\mathrm{N}$ & $\%$ \\
\hline \multirow{2}{*}{ Cinsiyet } & Kadın & 307 & 78,72 \\
\hline & Erkek & 83 & 21,28 \\
\hline \multirow{3}{*}{ Bölüm } & Fen Bil. Öğrt. & 162 & 41,54 \\
\hline & Matematik Öğrt. & 75 & 19,23 \\
\hline & Sınıf Öğrt. & 153 & 39,23 \\
\hline \multirow{4}{*}{ Sinif } & Birinci Sınıf & 123 & 31,54 \\
\hline & İkinci Sınıf & 117 & 30 \\
\hline & Üçüncü Sınıf & 115 & 29,5 \\
\hline & Dördüncü Sınıf & 35 & 8,97 \\
\hline
\end{tabular}

\section{Veri Toplama Araçları}

Araştırmada veri toplama aracı olarak "Ana Dilde Illetişim Yetkinliği Ölçeği” geliştirilmiş ve uygulanmıştır (EK-1).

\section{İşlem}

\section{Ana Dilde İletişim Ölçeğinin Geliştirilmesi Alan yazın taraması}

Ana dilde iletişim yetkinliği ile ilgili "Ana Dilde Illetişim”, "Ana Dil Eğitimi", "Türkçe Eğitimi” ve "Dil Yetkinliği" kavramları ile ilgili literatür taraması yapılmıştır. Literatür taraması esnasında hem ulusal kaynaklardan hem de uluslararası kaynaklardan faydalanılmıştır.

\section{Madde havuzunun oluşturulması}

Literatür taramasının ardından 26 maddeden oluşan bir taslak havuzu oluşturulmuştur. Ölçek maddelerinin hazırlanması esnasında maddelerin açık ve anlaşılır cümleler içermesine ve farklı anlamlara gelmeyecek ifadelerden oluşmasına dikkat edilmiştir. Maddeler hazırlanırken taraflı olmamasına dikkat edilmiştir. Bireyleri yönlendirecek ifadelere yer verilmemesine özen gösterilmiştir. Ölçek maddelerinin dil açısından anlaşılabilirliğinin belirlenmesi için dil alanında yetkin bir uzmana kontrol ettirilmiştir.

\section{Uzman görüşü alma}

Hazırlanan madde havuzunun kapsam geçerliliğini belirlemek amacıyla uzman görüşüne başvurulur (Büyüköztürk, Kılıç Çakmak, Akgün, Karadeniz ve Demirel, 2013). Bu aşamada iki fen öğretimi (bir Prof. Dr. - bir Doç. Dr.), iki ölçme değerlendirme alanında çalışmaları olan (iki Dr. Öğr. Üyesi) öğretim üyelerinin ve Türkçe eğitimi alanında çalışmaları olan bir Dr. Öğr. Üyesinin görüşleri uzman görüşü formu kullanılarak alınmıştır. Soruların uygunluğuna ilişkin uzman görüşlerinin 
belirlenmesi amacıyla "uygun" , "uygun değil" seçeneklerini içeren iki seçenekli bir cevap formu kullanılmıştır. Uzmanlardan her bir madde için değerlendirme yapmaları, seçeneklerden birini işaretlemeleri istenmiştir. "Uygun değil" seçeneğini işaretleyen uzmanlardan, belirtilen maddenin açıklama kısmına neden uygun olmadığına dair gerekçelerini yazmaları istenmiştir. Uzmanlardan gelen geri dönüşler neticesinde \%90-100 oranında olan maddeler doğrudan kabul edilmiş, \%70-80 oranında olan maddelerde düzenlemeye gidilmiştir (Büyüköztürk vd., 2013). \%70-80 oranının altında bir değere sahip olan 2 madde ölçekten çıkarılmıştır.

\section{Ölçeğin uygulanması ve verilerin toplanması}

Uzman görüşünün ardından şekillenen yeni ölçek, 24 maddeden oluşmaktadır. Öğretmen adaylarının maddelere katılma düzeylerinin belirlenmesi amacıyla 5'li likert tipinde hazırlanan ölçek; "Kesinlikle Katılmıyorum (1)", "Katılmıyorum (2)", "Kararsızım (3)", "Katılıyorum (4)", "Kesinlikle Katılıyorum (5)" şeklinde oluşturulmuştur. 31 maddeden oluşan ölçek, Eskişehir Osmangazi Üniversitesi Eğitim Fakültesinde öğrenim gören İlköğretim Matematik Öğretmenliği, Fen Bilgisi Öğretmenliği ve Sınıf Öğretmenliği öğretmen adaylarına uygulanmıştır. Ölçek uygulanmadan önce öğretmen adaylarına, araştırmanın amacı ve uygulama esnasında dikkat etmeleri gereken konular hakkında bilgilendirme yapılmıştır. Ölçeğin uygulanma süreci yaklaşık olarak 10-15 dakika sürmüştür.

\section{Verilerin analizi}

Eskişehir Osmangazi Üniversitesi Eğitim Fakültesi illköğretim Matematik Öğretmenliği, Fen Bilgisi Öğretmenliği ve Sınıf Öğretmenliğinde öğrenim gören toplam 390 öğretmen adayından veri toplanmıştır. Veri toplama aşamasında tam doldurulmamış ölçekler ve katılımcıların maddelerin hepsine aynı seçeneği işaretlediği formlar değerlendirilmemiş, çalışma grubundan çıkarılmıştır. Geriye kalan 390 veri bilgisayar ortamına aktarılarak faktör analizleri gerçekleştirilmiştir.

\section{Faktör Analizi}

Faktör analizi; ölçek uyarlama ve geliştirme çalışmalarında yapı geçerliliği için, ölçme aracını belirlemek için, daha önce belirlenmiş faktör yapısını test ederek doğruluğunu veya yanlışlığını ortaya koymak için, alt ölçekleri belirlemek için, ilişkili çok sayıda değişkeni birleştirerek daha az sayıda anlamlı değişkenler oluşturmak için kullanılır (Büyüköztürk, 2002).

Tablo 2.

KMO ve Bartlett's Testi

\begin{tabular}{lll}
\hline Kaiser- Meyer- Olkin (KMO) Değeri & &, 854 \\
\hline Bartlett's Küresellik Testi Sonuçları & Ki kare & 2873,463 \\
\hline & df & 276 \\
\hline & $p$ & 0,000 \\
\hline
\end{tabular}

Faktör analizi için ön şartlardan biri, KMO- Bartlett's Testi'dir. KMO değeri 0,6'dan büyük olmalı (KMO> 0,6) ve Bartlett's Sig. değeri 0,05'ten küçük (Bartlett's sig <0,05) olmalıdır (Büyüköztürk, 2002). KMO ve Bartlett's Testi sonucunun anlamlı olması, ölçeğimizin faktör analizine uygunluğunu gösterir (Yaşlıŏlu, 2017). Tablo 2'de, ölçeğimize ait KMO ve Bartlett's Testi'ne ait sonuçlar verilmiştir. KMO değerinin 0,85 olduğu görülmüştür. Bu değer, 0,6 'dan büyük $(0,85>0,6)$ olduğu için sonuç anlamlıdır. Bartlett's Testi değeri 2873,463 ve serbestlik derecesi 276 olup sonuç anlamlıdır. $(p=0,000, p<0,05)$.

Tablo 3.

Ana Dilde Iletişim Yetkinliği Ölçeğinin Faktör Yükleri

\begin{tabular}{lc}
\hline & Faktör Yük Değeri \\
\hline 1. Öğrendiğim kavramları sözel olarak ifade ederim. &, 386 \\
\hline 2. Eğitim konusundaki düşüncelerimi ifade ederim. &, 469 \\
\hline 3. Konuyu ilk okuduğumda anlarım. &, 736 \\
\hline
\end{tabular}




\begin{tabular}{lc}
\hline 4. Düşüncelerimi rahatça ifade ederim. &, 523 \\
\hline 5. Okuduğum problemi tek seferde anlarım. &, 686 \\
\hline 6. Arkadaşlarımla iletişimim gü̧̧̈̈dür. &, 660 \\
\hline 7. Arkadaşlarımla sözlü iletişım kurarken sıkıntı yaşamam. &, 646 \\
\hline 8. Arkadaşlarımla dijital ortamda iletişim kurarım. &, 453 \\
\hline 9. Kendimi yazııı olarak ifade ederim. &, 626 \\
\hline 10. Türkçeyi hatasız konuşurum. &, 621 \\
\hline 11. Arkadaşlarımın eleştirilerini dikkate alıım. &, 576 \\
\hline 12. Bilimsel konularda konuşmayı severim. &, 682 \\
\hline 13. Bilimsel dergiler ilgi çekicidir. &, 776 \\
\hline 14. Duygu ve düşüncelerimi arkadaşlarıma ifade etmekten hoşlanırım. &, 471 \\
\hline 15. Derste arkadaşlarımın karşısında sunum yapmaktan hoşlanırım. &, 456 \\
\hline 16. Ana dilimi etkili bir şekilde kullanırım. &, 601 \\
\hline 17. Çevremdeki insanlarla etkili bir şekilde iletişim kurabilirim. &, 597 \\
\hline 18. Sosyal çevremde ana dilimi etkili kullanmanın önemli olduğunu &, 515 \\
\hline 19. Başarılı insanların iletişim becerilerinin yüksek olduğunu bilirim. &, 577 \\
\hline 20. Öğretmenlik mesleğinde etkili iletişimin önemli olduğunu bilirim. &, 492 \\
\hline 21. Ana dilimi sözlü ve yazılı olarak etkin bir şekilde kullanırım. &, 505 \\
\hline 22. Düşüncelerimi yazılı olarak ifade ederim. &, 692 \\
\hline 23. Düşüncelerimi sözlü olarak ifade ederim. &, 526 \\
\hline 24. Öğrencilerim ile nasıl iletişim kuracağımı bilirim. &, 364 \\
\hline
\end{tabular}

Tablo 3'te, her bir faktör değerinin toplam faktörde ne kadarlık bir etki oluşturduğu görülmektedir. Bu tablodaki sonuçlara dayanarak 0,30'un altındaki değerler ölçekten çıkarılır (Özdamar, 2004). Madde 3: \%73'lük değeri ve Madde 13: \%77'lik değeri ile toplam faktörü şekillendirmede en çok etkileyen maddelerdir.

Tablo 4.

Ana Dilde Illetişim Yetkinliği Ölçeği Faktör Katsayıları

\begin{tabular}{|c|c|c|c|c|c|c|}
\hline & 1 & 2 & 3 & 4 & 5 & 6 \\
\hline 6. Arkadaşlarımla iletişimim güçlüdür. & ,706 &,- 088 &,- 172 & ,182 &,- 235 &,- 187 \\
\hline $\begin{array}{l}\text { 7. Arkadaşlarımla sözlü iletişim kurarken sıkıntı } \\
\text { yaşamam. }\end{array}$ & 699 &,- 116 &,- 224 & 190 &,- 141 &,- 197 \\
\hline $\begin{array}{l}\text { 17. Çevremdeki insanlarla etkili bir şekilde iletişim } \\
\text { kurabilirim. }\end{array}$ & 690 & 132 &,- 115 & 053 & ,090 &,- 281 \\
\hline 4. Düşüncelerimi rahatça ifade ederim. & 659 &,- 287 & ,023 & ,003 &,- 038 &,- 065 \\
\hline 23. Düşüncelerimi sözlü olarak ifade ederim. & 647 &,- 065 &,- 228 & 061 & 190 & ,112 \\
\hline 16. Ana dilimi etkili bir şekilde kullanırım. & ,583 & ,306 &,- 049 &,- 127 & 214 & 321 \\
\hline 5. Okuduğum problemi tek seferde anlarım. & ,568 & 054 & 065 &,- 506 &,- 315 &,- 036 \\
\hline $\begin{array}{l}\text { 18. Sosyal çevremde ana dilimi etkili kullanmanın } \\
\text { önemli olduğunu bilirim. }\end{array}$ &, 552 & ,421 &,- 004 & 085 &,- 117 &,- 110 \\
\hline 1. Öğrendiğim kavramları sözel olarak ifade ederim. & ,548 &,- 220 & ,046 &,- 055 &,- 162 &,- 073 \\
\hline 22. Düşüncelerimi yazılı olarak ifade ederim. & 546 & ,215 &,- 148 &,- 069 & ,371 & 428 \\
\hline 2. Eğitim konusundaki düşüncelerimi ifade ederim. & ,511 &,- 280 & 238 & 153 & -197 &,- 101 \\
\hline
\end{tabular}




\begin{tabular}{|c|c|c|c|c|c|c|}
\hline $\begin{array}{l}\text { 21. Ana dilimi sözlü veya yazılı olarak etkin bir } \\
\text { şekilde kullanırım. }\end{array}$ & ,495 &,- 392 &,- 007 &,- 050 & ,270 & 176 \\
\hline 10. Türkçeyi hatasız konuşurum. & ,468 &,- 293 & ,017 &,- 412 & 367 & 107 \\
\hline $\begin{array}{l}\text { 14. Duygu ve düşüncelerimi arkadaşlarıma ifade } \\
\text { etmekten hoşlanırım. }\end{array}$ & ,466 & ,272 & 182 & ,378 & ,045 &,- 038 \\
\hline 24. Öğrencilerim ile nasıl iletişim kuracağımı bilirim. & ,463 &,- 217 &,- 199 & 160 & 188 &,- 037 \\
\hline 8. Arkadaşlarımla dijital ortamda iletişim kurarım. & ,420 &,- 065 &,- 283 & 264 &,- 114 & 331 \\
\hline 9. Kendimi yazılı olarak ifade ederim. & ,287 & 645 &,- 187 &,- 011 & 235 & 193 \\
\hline 11. Arkadaşlarımın eleştirilerini dikkate alırım. & ,409 & ,595 & 144 &,- 172 & 027 &,- 059 \\
\hline $\begin{array}{l}\text { 15. Derste arkadaşlarımın karşısında sunum } \\
\text { yapmaktan hoşlanırım. }\end{array}$ & 355 &,- 557 &,- 012 & 077 & 119 &,- 007 \\
\hline $\begin{array}{l}\text { 20. Öğretmenlik mesleğinde etkili iletişimin önemli } \\
\text { olduğunu bilirim. }\end{array}$ & 358 & ,455 & 109 & 171 &,- 276 & 199 \\
\hline 13. Bilimsel dergiler ilgi çekicidir. & 236 & 137 & 815 & ,076 & 179 & ,003 \\
\hline 12. Bilimsel konularda konuşmayı severim. & ,303 &,- 186 & 712 & 115 & 187 &,- 003 \\
\hline 3. Konuyu ilk okuduğumda anlarım. &, 521 &,- 042 & 084 &,- 563 &,- 346 & 136 \\
\hline $\begin{array}{l}\text { 19. Başarılı insanların iletişim becerilerinin yüksek } \\
\text { olduğunu düşünürüm. }\end{array}$ & ,267 &,- 106 & 177 & 167 &,- 356 & ,555 \\
\hline
\end{tabular}

Tablo 4'te, her bir maddenin yüklerinin en az 0,30 olması gerekmektedir. Faktörde yer alan maddelerin yük değerlerinin yüksek olması bu maddelerin birlikte, kavramı ya da faktörü ölçebildiğini gösterir. 0,40 ve daha yüksek değerler, faktör yük değerleri için iyi bir ölçüdür. Ancak birçok uygulamada bazı maddeler için bu değer 0,30'a kadar inebilmektedir. Bazı maddeler birden fazla faktörden yük alabilir. Bazı maddeler de bunun aksine hiçbir faktörden yüksek bir değer almayabilir (Büyüköztürk, 2002).

Tablo 5.

Ana Dilde Iletişim Yetkinliği Ölçeği Döndürülmüş Faktör Dağılımı

\begin{tabular}{|c|c|c|c|c|c|c|}
\hline & \multicolumn{6}{|c|}{ Faktör Dağılımı } \\
\hline & 1 & 2 & 3 & 4 & 5 & 6 \\
\hline $\begin{array}{l}\text { 7. Arkadaşlarımla sözlü iletişim kurarken sıkıntı } \\
\text { yaşamam. }\end{array}$ & 758 & - & - & - & - & - \\
\hline 6. Arkadaşlarımla iletişimim güçlüdür. & ,757 & - & - & - & - & - \\
\hline $\begin{array}{l}\text { 17. Çevremdeki insanlarla etkili bir şekilde iletişim } \\
\text { kurabilirim. }\end{array}$ & ,590 & - & - & - & - & - \\
\hline 4. Düşüncelerimi rahatça ifade ederim. & ,580 & - & - & - & - & - \\
\hline 2. Eğitim konusundaki düşüncelerimi ifade ederim. &, 539 & - & - & - & - & - \\
\hline 1. Öğrendiğim kavramları sözel olarak ifade ederim. & 486 & - & - & - & - & - \\
\hline 24. Öğrencilerim ile nasıl iletişim kuracağımı bilirim. & 466 & - & - & - & - & - \\
\hline $\begin{array}{l}\text { 15. Derste arkadaşlarımın karşısında sunum } \\
\text { yapmaktan hoşlanırım. }\end{array}$ & ,423 & - & - & - & - & - \\
\hline 9. Kendimi yazılı olarak ifade ederim. & - & ,752 & - & - & - & - \\
\hline 11. Arkadaşlarımın eleştirilerini dikkate alırım. & - & 689 & - & - & - & - \\
\hline $\begin{array}{l}\text { 18. Sosyal çevremde ana dilimi etkili kullanmanın } \\
\text { önemli olduğunu bilirim. }\end{array}$ & - & ,585 & - & - & - & - \\
\hline 16. Ana dilimi etkili bir şekilde kullanııım. & - &, 535 & - & - & - & - \\
\hline $\begin{array}{l}\text { 20. Öğretmenlik mesleğinde etkili iletişimin önemli } \\
\text { olduğunu bilirim. }\end{array}$ & - & 521 & - & - & - & - \\
\hline
\end{tabular}




\begin{tabular}{|c|c|c|c|c|c|c|}
\hline $\begin{array}{l}\text { 14. Duygu ve düşüncelerimi arkadaşlarıma ifade } \\
\text { etmekten hoşlanırım. }\end{array}$ & - & ,447 & - & - & - & - \\
\hline 10. Türkçeyi hatasız konuşurum. & & - & 679 & - & - & - \\
\hline 22. Düşüncelerimi yazılı olarak ifade ederim. & - & - &, 616 & - & - & - \\
\hline $\begin{array}{l}\text { 21. Ana dilimi sözlü ve yazılı olarak etkin bir şekilde } \\
\text { kullanırım. }\end{array}$ & - & - & 602 & & & \\
\hline 23. Düşüncelerimi sözlü olarak ifade ederim. & - & - & ,482 & - & - & - \\
\hline 13. Bilimsel dergiler ilgi çekicidir. & - & - & - & 853 & - & - \\
\hline 12. Bilimsel konularda konuşmayı severim. & - & - & - & ,797 & - & - \\
\hline 3. Konuyu ilk okuduğumda anlarım. & - & - & - & - & 805 & - \\
\hline 5. Okuduğum problemi tek seferde anlarım. & - & - & - & - & ,751 & - \\
\hline $\begin{array}{l}\text { 19. Başarılı insanların iletişim becerilerinin yüksek } \\
\text { olduğunu düşünürüm. }\end{array}$ & - & - & - & - & - & ,719 \\
\hline 8. Arkadaşlarımla dijital ortamda iletişim kurarım. & - & - & - & - & - & 463 \\
\hline
\end{tabular}

Tablo 5'te, hangi maddenin hangi faktöre girdiğine faktör yüklerine bakılarak karar verilir. Yük, Madde 11-14-16-18 ve 20 yer almaktadır. Faktör 3'te, Madde 10-21-22 ve 23 yer almaktadır. Faktör 4 'te, Madde 12 ve 13 yer almaktadır. Faktör 5'te, Madde 3 ve 5 yer almaktadır. Faktör 6'da, Madde 8 ve 19 yer almaktadır.

Yapılan analizler sonucunda en düşük faktör yük değerine sahip olan Madde 1 ve Madde 24 ölçekten çıkarılmıştır. 22 maddelik ölçeğin geçerlik ve güvenirlik işlemlerinin ardından ölçek son hâlini almıştır. Teorik çerçeve doğrultusunda ölçekte alt boyutlar oluşturulmamıştır.

\section{Verilerin Toplanması}

Araştırma kapsamında geliştirilen Ana Dilde Iletişim Yetkinliği Ölçeği; 2019-2020 eğitim ve öğretim yılı güz döneminde Eskişehir Osmangazi Üniversitesi Eğitim Fakültesi Fen Bilimleri Öğretmenliği, Matematik Öğretmenliği ve Sınıf Öğretmenliği bölümlerinde öğrenimine devam eden 390 öğretmen adayına uygulanmıştır.

\section{Verilerin Analizi}

Ham veriler düzenlenerek analizlerin yapılacağı veri seti oluşturulmuştur. Hangi analizlerin yapılacağına karar vermek amacıyla öncelikle normallik testi yapılmıştır. Bu analiz sonucunda, Kolmogrov-Smirnov değeri $(p>0,05)$ göz önüne alınarak verilerin normal dağıldığı tespit edilmiştir. Normal dağılım gösteren verilerimiz için parametrik testler kullanılmıştır. Veriler, bir istatistik paket programı kullanılarak analiz edilmiştir. Öğretmen adaylarının ana dilde iletişim yetkinliği: cinsiyet, okudukları bölümden memnun olma, STEM eğitimi alma, argümantasyon eğitimi alma durumuna göre anlamlı bir farklılık gösterip göstermediğini belirlemek amacıyla bağımsız gruplar t- testi, sınıf ve bölüm değişkenlerine göre anlamlı bir farklılık gösterip göstermediğini belirlemek amacıyla tek yönlü varyans (ANOVA) analizi yapılmıştır.

\section{Geçerlik ve Güvenirlik}

Bu çalışmada ölçeğin toplam Cronbach alfa kat sayısı değeri 0,85 olarak hesaplanmıştır. Cronbach alfa katsayısı; $0,00 \leq \alpha \leq 0,40$ ise ölçek güvenilir değildir, $0,40 \leq \alpha \leq 0,60$ ise ölçek düşük güvenirliktedir, $0,60 \leq \alpha \leq 0,80$ ise oldukça güvenilirdir, $0,80 \leq \alpha \leq 1,00$ ise ölçek yüksek derecede güvenilirdir (Tavşancıl, 2006). Bu ölçütler dikkate alındığında çalışmada geliştirilen ana dilde iletişim yetkinliği ölçeğinin yüksek güvenirliğe sahip olduğu söylenebilir.

\section{Araştırma ve Yayın Etiği}

Bu çalışmada "Yükseköğretim Kurumları Bilimsel Araştırma ve Yayın Etiği Yönergesi" kapsamında uyulması belirtilen tüm kurallara uyulmuştur. Yönergenin ikinci bölümü olan "Bilimsel 
Araştırma ve Yayın Etiğine Aykırı Eylemler" başlığı altında belirtilen eylemlerden hiçbiri gerçekleştirilmemiştir.

\section{Etik Kurul İzni}

Kurul adı = Eskişehir Osmangazi Üniversitesi Sosyal ve Beşeri Bilimler Bilimsel Araştırma ve Yayın Etiği Kurulu

Karar tarihi= 04.12.2019

Belge sayı numarası $=64075176-299-E .83350$

\section{Bulgular}

Bu bölümde, yapılan analizlerinden elde edilen bulgulara yer verilmiştir. Hangi analizlerin yapılacağına karar vermek için normallik testi gerçekleştirilmiştir. Normallik testi sonucunda Kolmogrov - Smirnov değerinin 0,05'ten büyük olması sebebiyle verilerin normal dağıldığı tespit edilmiştir. Normal dağılım gösteren verilere uygun olan parametrik testler kullanılmıştır. Öğretmen adaylarının ana dilde iletişim yetkinliği düzeylerine ait tanımlayıc istatistikler Tablo 6'da verilmiştir. Tablo 6'da görüldüğü üzere, çalışmaya 390 öğretmen adayı katılmıştır. Yapılan analizler sonucunda ortalama 84,04 ve standart sapma 9,238 olarak bulunmuştur.

Tablo 6.

Ana Dilde Iletişim Yetkinlik Düzeylerine Ait Tanımlayıcı Istatistikler

\begin{tabular}{lccc}
\hline & $\mathrm{N}$ & $\bar{X}$ & $\mathrm{~S}$ \\
\hline Ana Dilde İletişim Yetkinliği Ölçeği & 390 & 84,04 & 9,238 \\
\hline
\end{tabular}

Araştırmaya katılan öğretmen adaylarının ana dilde iletişim yetkinliklerinin cinsiyete göre farklılık gösterip göstermediğini belirlemek amacıyla yapılan t- testi sonuçları Tablo 7'de verilmiştir.

Tablo 7.

Cinsiyet Değişkenine Ait t- Testi Sonuçları

\begin{tabular}{cccccc}
\hline & $\mathrm{N}$ & $\overline{\mathrm{X}}$ & $\mathrm{s}$ & $\mathrm{T}$ & $\mathrm{P}$ \\
\cline { 1 - 4 } Kadın & 307 & 84,39 & 8,865 & \multirow{2}{*}{1,422} & 0,156 \\
\hline Erkek & 83 & 82,77 & 10,462 & & \\
\hline
\end{tabular}

Tablo 7’de görüldüğü üzere, öğretmen adaylarının ana dilde iletişim yetkinliklerinin cinsiyet değişkenine göre anlamlı bir farklılık olup olmadığının tespiti amacıyla yapılan t- testi sonucuna göre kadın ve erkek öğretmen adayları arasında anlamlı bir farklılık bulunamamıştır $(P=0,156>0,05)$.

Ana dilde iletişim yetkinliğinin öğretmen adaylarının STEM eğitimi alıp almama durumlarına göre farklılık gösterip göstermediğini belirlemek amacıyla yapılan t- testi sonuçları Tablo 8'de verilmiştir.

Tablo 8.

STEM Eğitimi Alma Değişkenine Ait t- Testi Sonuçları

\begin{tabular}{|c|c|c|c|c|c|}
\hline & $\mathrm{N}$ & $\bar{X}$ & $S$ & $t$ & $P$ \\
\hline Evet & 62 & 87,08 & 7,998 & \multirow{2}{*}{2,843} & \multirow{2}{*}{0,005} \\
\hline Hayır & 328 & 83,47 & 9,355 & & \\
\hline
\end{tabular}

Tablo 8'de görüldüğü üzere, öğretmen adaylarının ana dilde iletişim yetkinliklerinin STEM eğitimi alıp almama değişkenine göre anlamlı bir farklılık olup olmadığının tespiti amacıyla yapılan ttesti sonucuna göre STEM eğitimi alan ve almayan öğretmen adayları arasında anlamlı bir farklılık bulunmuştur $(p=0,005<0,05)$. Bu fark, STEM eğitimi alan öğretmen adayları lehinedir. 
Öğretmen adaylarının ana dilde iletişim yetkinliğinin argümantasyon eğitimi alıp almama durumlarına göre farklılık gösterip göstermediğini belirlemek amacıyla yapılan t- testi sonuçları Tablo 9'da verilmiştir.

Tablo 9.

Argümantasyon Eğitimi Alma Değişkenine Ait t- Testi Sonuçları Değişkeni

\begin{tabular}{cccccc}
\hline & $\mathrm{N}$ & $\bar{X}$ & $\mathrm{~S}$ & $\mathrm{t}$ & $\mathrm{P}$ \\
\hline Evet & 23 & 88,17 & 9,417 & \multirow{2}{*}{2,219} & \multirow{2}{*}{0,027} \\
\hline Hayır & 367 & 83,79 & 9,178 & \\
\hline
\end{tabular}

Tablo 9'da görüldüğü üzere, öğretmen adaylarının ana dilde iletişim yetkinliklerinin argümantasyon eğitimi alıp almama değişkenine göre anlamlı bir farklılık olup olmadığının tespiti amacıyla yapılan t- testi sonucuna göre argümantasyon eğitimi alan ve almayan adaylar arasında anlamlı bir farklılık bulunmuştur $(\mathrm{p}=0,027<0,05)$. Bu fark, argümantasyon eğitimi alan öğretmen adayları lehinedir.

Öğretmen adaylarının ana dilde iletişim yetkinliğinin okudukları bölümden memnuniyet durumlarına göre farklılık gösterip göstermediğini belirlemek amacıyla yapılan t- testi sonuçları Tablo $10^{\prime}$ da verilmiştir.

Tablo 10.

Okudukları Bölümden Memnun Olma Değişkenine Ait t-Testi Sonuçları

\begin{tabular}{cccccc}
\hline & $\mathrm{N}$ & $\bar{X}$ & $\mathrm{~S}$ & $\mathrm{t}$ & $\mathrm{P}$ \\
\hline Evet & 354 & 84,50 & 8,738 & \multirow{2}{*}{2,340} & \multirow{2}{*}{0,025} \\
\hline Hayır & 36 & 79,52 & 12,465 & & \\
\hline
\end{tabular}

Tablo $10^{\prime}$ da görüldüğü üzere, öğretmen adaylarının ana dilde iletişim yetkinliklerinin okudukları bölümden memnuniyet durumları değişkenine göre anlamlı bir farklılık olup olmadığının tespiti amacıyla yapılan $\mathrm{t}$ - testi sonucuna göre okuduğu bölümden memnun olan ve olmayan öğretmen adayları arasında anlamlı bir farklılık bulunmuştur $(p=0,025<0,05)$. Bu fark, okuduğu bölümden memnun olan adaylar lehinedir.

Öğretmen adaylarının ana dilde iletişim yetkinliğinin sınıf değişkenine göre farklılık gösterip göstermediğini belirlemek amacıyla yapılan ANOVA testi sonuçları Tablo 11'de verilmiştir.

Tablo 11.

Sınıf Değişkenine Ait ANOVA Testi Sonuçları

\begin{tabular}{|c|c|c|c|c|c|c|}
\hline & $\begin{array}{c}\text { Kareler } \\
\text { Toplamı }\end{array}$ & sd & $\begin{array}{c}\text { Kareler } \\
\text { Ortalaması }\end{array}$ & $\mathrm{F}$ & $\mathrm{p}$ & Farklılaşma \\
\hline $\begin{array}{c}\text { Gruplar } \\
\text { Arası }\end{array}$ & 455,759 & 3 & 151,920 & \multirow{3}{*}{1,791} & \multirow{3}{*}{0,148} & \multirow{3}{*}{ Fark yok } \\
\hline Gruplar içi & 32746,315 & 386 & 84,835 & & & \\
\hline Toplam & 33202,074 & 389 & & & & \\
\hline
\end{tabular}

Tablo 11 'de görüldüğü üzere, öğretmen adaylarının ana dilde iletişim yetkinliklerinin sınıf değişkenine göre anlamlı bir farklıık olup olmadığının tespiti amacıyla yapılan ANOVA testi sonucuna göre karşılaştırılan gruplar arasında anlamlı bir fark bulunmamıştır ( $p=0,148>0,05)$.

Öğretmen adaylarının ana dilde iletişim yetkinliğinin bölüm değişkenine göre farklılık gösterip göstermediğini belirlemek amacıyla yapılan ANOVA testi sonuçları Tablo 12' de verilmiştir. 
Tablo 12.

Bölüm Değişkenine Ait ANOVA Testi Sonuçları

\begin{tabular}{|c|c|c|c|c|c|c|}
\hline & $\begin{array}{l}\text { Kareler } \\
\text { Toplamı }\end{array}$ & sd & $\begin{array}{c}\text { Kareler } \\
\text { Ortalaması }\end{array}$ & $F$ & $p$ & Farklılaşma \\
\hline $\begin{array}{c}\text { Gruplar } \\
\text { Arası }\end{array}$ & 1332,898 & 2 & 666,449 & \multirow{3}{*}{8,093} & \multirow{3}{*}{0,000} & $\begin{array}{l}\text { Sinıf-Fen } \\
\text { Sinıf-Mat }\end{array}$ \\
\hline Gruplar İçi & 31869,176 & 387 & 82,349 & & & Fen-Sınıf \\
\hline Toplam & 33202,074 & 389 & & & & $\begin{array}{l}\text { Mat-Sınıf } \\
\text { Mat-Fen }\end{array}$ \\
\hline
\end{tabular}

Tablo 12 'de görüldüğü üzere, öğretmen adaylarının ana dilde iletişim yetkinliklerinin bölüm değişkenine göre anlamlı bir farklılık olup olmadığının tespiti amacıyla yapılan ANOVA testi sonucuna göre gruplar arasında anlamlı bir farklılık bulunmuştur $(p=0,000<0,05)$. Anlamlı farka bakıldığında sınıf öğretmenliği ile fen bilimleri öğretmenliği ve matematik öğretmenliği arasında sınıf öğretmenliği lehine, fen bilimleri öğretmenliği ile sınıf öğretmenliği ve matematik öğretmenliği arasında fen bilimleri öğretmenliği lehine, matematik öğretmenliği ile sınıf öğretmenliği ve fen bilimleri öğretmenliği arasında matematik öğretmenliği lehine çıktığı görülmektedir.

\section{Tartışma ve Sonuç}

Bu çalışmada 22 maddelik "Ana Dilde iletişim Ölçeği" geliştirilmiştir. Açımlayıcı faktör analizi sonuçları ana dilde iletişim yetkinliğini belirlemek amacıyla geliştirilmiş olan ölçeğin geçerli ve güvenilir bir ölçme aracı olduğunu göstermektedir. Ölçeğin geneline ilişkin hesaplanan Cronbach's Alpha değeri 0.857 bulunmuştur. Bu değer, güvenirlik kategorilerinde iyi bir değer olarak kabul edilmektedir. Ölçek bileşenleri, toplam varyansın \%56,824'ünü açıklamaktadır. Ölçek bileşenlerinin kendi aralarında ve ölçeğin toplam puanıyla pozitif yönde yüksek düzeyde ilişki gösteriyor olması, ölçeğin tek boyutlu bir yapı sergilediğini göstermektedir. Geliştirilen ölçeğin yapılan analiz sonuçları dikkate alındığında, ölçeğin öğretmen adaylarının ana dilde iletişim yetkinliklerini belirlemek amacıyla kullanılabilir bir ölçme aracı olduğunu göstermektedir.

Geliştirilen ölçeğin yapı geçerliliğinin kanıtı olarak ana dilde iletişim yetkinliği puanları, fark testlerine göre incelenmiştir. Öğretmen adaylarının ana dilde iletişim yetkinlikleri, cinsiyet, STEM eğitimi alıp almama durumu, argümantasyon eğitimi alıp almama durumu, okudukları bölümden memnun olma durumları, sınıf ve öğrenim gördükleri bölüm değişkenine göre incelenmiştir.

Öğretmen adaylarının ana dilde iletişim yetkinliklerinde cinsiyet değişkenine göre anlamlı bir farklılık bulunamamıştır. Durmuşçelebi (2013), yaptığı çalışmada ana dilde okuduğunu anlamanın cinsiyet değişkenine göre anlamlı bir farklılık göstermediğini bulmuştur. Oral ve Yazar (2015), öğretmen adaylarının yaşam boyu öğrenmeye ilişkin algılarını belirlemek amacıyla yaptıkları çalışmada cinsiyet değişkenine göre anlamlı bir farklılık göstermediğini bulmuştur. Durmuşçelebi (2013) ile Oral ve Yazar'ın (2015) yapmış oldukları çalışmalar bu çalışmanın sonucunu destekler niteliktedir.

Öğretmen adaylarının ana dilde iletişim yetkinliklerinde STEM eğitimi alıp almama değişkenine göre anlamlı bir fark bulunmuştur. Bu farklılık STEM eğitimi alan öğretmen adayları lehinedir. Avrupa Birliği Resmi Gazetesi'nde (2018) yayınlanan anahtar yetkinliklere ilişkin konsey tavsiye kararında bilim, teknoloji, mühendislik ve matematikte (STEM) bilimsel yöntemlerin bir dizi yetkinliğin gelişimini teşvik edeceği belirtilmiştir. Bahar, Yener, Yılmaz, Emen ve Gürer (2018) çalışmalarında "STEM temelli yürütülen etkinliklerin öğrencilerde çok farklı yetkinlik ve becerilerin gelişmesine imkân sağladığını" belirtmiş̧ir. Akgül ve Yıldırım (2018), yaptıkları çalışmada STEM etkinliklerinin öğrencilerin sunum yapma ve araştırma becerilerinin gelişmesine katkı sağladığı sonucuna ulaşmıştır. Bu çalışmalar elde edilen sonucu destekler niteliktedir.

Öğretmen adaylarının ana dilde iletişim yetkinliklerinde argümantasyon eğitimi alıp almama değişkenine göre anlamlı bir fark bulunmuştur. Bu farklılık argümantasyon eğitimi alan öğretmen adayları lehinedir. Kardaş (2013), yaptığı çalışmada argümantasyon eğitiminin öğrencilerin karar verme becerilerine olumlu etki yaptığını dile getirmiştir. Aktaş (2017), çalışmasında argümantasyona dayalı 
sorgulama modeli kullanılarak işlenen derslerde akademik başarıda artış sağlandığını, öğrencilerin tartışmaya katılma düzeylerinde anlamlı bir artış bulunduğunu ve öğrencilerin daha kaliteli argümanlar oluşturdukları sonucuna ulaşmıştır. Literatür incelemesinde argümantasyona dayalı öğretimin öğrencilerin ana dilde iletişim yetkinliğine olumlu bir katkı yapacağı düşünülmektedir. Bu çalışmada da öğretmen adaylarının yetkinlik düzeylerin eğitim alan öğretmen adaylarının lehine olması bu görüşü destekler niteliktedir.

Öğretmen adaylarının ana dilde iletişim yetkinliklerinde okudukları bölümden memnun olup olmama değişkenine göre anlamlı bir farklılık bulunmuştur. Bu farklıık okuduğu bölümden memnun olan öğretmen adayları lehinedir. Çetinkaya (2007), yaptığı çalışmada okuduğu bölümden memnun olan öğrencilerin yeterlilik algıları ve mesleğe yönelik tutumlarının okuduğu bölümden memnun olmayan öğrencilere göre yüksek çıktığını sonucuna ulaşmıştır. Çetinkaya'nın (2007) elde ettiği sonuç bu çalışmayı destekler niteliktedir.

Öğretmen adaylarının ana dilde iletişim yetkinliklerinde sınıf değişkenine göre anlamlı bir farklııı bulunamamıştır. Araştırmadan elde edilen sonuçlardan farklı olarak Oral ve Yazar (2015), yaptıkları çalışmada sınıf düzeylerine göre anlamlı bir farklııık tespit etmişlerdir. Yılmaz ve Benli (2010), okuma alışanlıklarına yönelik tutumu belirlemek amacıyla yaptıkları çalışmada, öğretmen adaylarının sınıf düzeyi değişkenine göre anlamlı bir farklılık göstermediği sonucuna ulaşmıştır. Yılmaz ve Benli'nin (2010) elde ettiği sonuç bu çalışmanın sonucunu destekler niteliktedir.

Öğretmen adaylarının ana dilde iletişim yetkinliklerinde okudukları bölüm değişkenine göre anlamlı bir farklılık bulunmuştur. İzci ve Koç (2012), yaptıkları çalışmada öğretmen adaylarının okudukları bölüme göre yaşam boyu öğrenme algılarında anlamlı bir fark olduğunu tespit etmiştir. Evin Gencel (2013) çalışmasında, farklı anabilim dallarında öğrenim gören öğretmen adaylarının yaşam boyu öğrenme yeterliliklerinin okudukları bölüme göre farklılık gösterdiğini tespit etmiştir. Bu çalışmalar elde edilen sonucu destekler niteliktedir. Araştırmadan elde edilen sonuçlardan farklı olarak Oral ve Yazar (2015), yaptıkları çalışmada öğretmen adaylarının öğrenime devam ettikleri bölümlerine göre anlamlı bir fark bulamamışlardır.

Sonuç olarak geçerlik ve güvenirlik çalışmaları ve faktör analizine ilişkin bulgular göz önüne alındığında geliştirilmiş olan ölçeğin öğretmen adaylarının ana dilde iletişim yetkinlik düzeylerini belirlemek amacıyla kullanılabilir olduğunu göstermektedir. Bu çalışma ile birlikte alanyazına ana dilde iletişim yetkinlik düzeyinin belirlenebilmesi amacıyla geçerli ve güvenilir bir ölçme aracı kazandırılmıştır. Alanyazında ana dilde iletişim yetkinliği ölçeği kullanılarak özgün ve alana katkı getiren araştırmalar gerçekleştirilebilir.

\section{Araştırma ve Yayın Etiği}

Bu çalışmada "Yükseköğretim Kurumları Bilimsel Araştırma ve Yayın Etiği Yönergesi" kapsamında uyulması belirtilen tüm kurallara uyulmuştur. Yönergenin ikinci bölümü olan "Bilimsel Araştırma ve Yayın Etiğine Aykırı Eylemler" başlığı altında belirtilen eylemlerden hiçbiri gerçekleştirilmemiştir.

\section{Etik Kurul İni}

Kurul adı = Eskişehir Osmangazi Üniversitesi Sosyal ve Beşeri Bilimler Bilimsel Araştırma ve Yayın Etiği Kurulu

Karar tarihi= 04.12.2019

Belge sayı numarası $=64075176-299-E .83350$

\section{Yazarların Katkı Oranı}

Bu araştırmada 1. yazarın katkı oranı $\% 40$, 2. yazarın katkı oranı \%40, 3. yazarın katkı oranı $\% 20$ dir.

\section{Çıkar Çatışması}

Bu araştırmada çıkar çatışması teşkil edebilecek herhangi bir durum ya da ilişki yoktur. 


\section{Kaynaklar}

Açık Önkaş, N. (2010). Ana dili öğretimine yeni yaklaşımlar. Muğla Üniversitesi Sosyal Bilimler Enstitüsü Dergisi (ILKE), 24, 121-128.

Akgül, N. ve Yıldırım, B. (2018). STEM SOS modelinin farklı değişkenler açısından etkisinin incelenmesi. El-Cezeri Fen ve Mühendislik Dergisi, 5(2), 316-326. DOI: https://doi.org/10.31202/ecjse.376481

Aktaş, T. (2017). Argümantasyona dayalı sorgulama öğretiminin 7. sınıf öğrencilerinin kuvvet ve enerji ünitesindeki akademik başarılarına ve argümantasyon seviyelerine etkisi (Yayımlanmamış yüksek lisans tezi). Marmara Üniversitesi Eğitim Bilimleri Enstitüsü, İstanbul.

Avrupa Birliği Resmi Gazetesi (2018). Hayat Boyu Öğrenme İçin Anahtar Yetkinliklere ilişskin 22.05.2018 tarihli Konsey Tavsiye Kararı (2018/C 189/01). Erişim Adresi: https://www.myk.gov.tr/images/articles/TYC/Yayinlar/Hayat_Boyu_Ogrenme_icin_Anahtar_ Yetkinlikler_Tavsiye_Karari_2018.pdf

Bahar, M., Yener, D., Yılmaz, M., Emen, H. ve Gürer, F. (2018). 2018 Fen bilimleri öğretim programı kazanımlarındaki değişimler ve fen teknoloji matematik mühendislik (STEM) entegrasyonu. Abant İzet Baysal Üniversitesi Eğitim Fakültesi Dergisi, 18(2), 702-735. DOI: https://doi.org/10.17240/aibuefd.2018..-412111

Büyüköztürk, Ş. (2002). Faktör analizi: Temel kavramlar ve ölçek geliştirmede kullanımı. Kuram ve Uygulamada Eğitim Yönetimi, 32, 470-483.

Büyüköztürk, Ş., Kılıç Çakmak, E., Akgün, Ö.E., Karadeniz, Ş. ve Demirel, F. (2013). Bilimsel araştırma yöntemleri. Ankara: Pegem Akademi.

Ceran, D. ve Deniz, K. (2015). TEOG sınavı sorularının okuma becerisiyle çözülebilme düzeyi. Ana Dili Eğitimi Dergisi, 3(2), 92-109. DOI: https://doi.org/10.16916/aded.62200

Çetinkaya, R. (2007). Türkçe öğretmeni adaylarının yeterlilik algıları ve öğretmenlik mesleğine yönelik tutumları (Yayımlanmamış yüksek lisans tezi). Selçuk Üniversitesi Sosyal Bilimler Enstitüsü, Konya.

Durmuşçelebi, M. (2013). Anadilde okuma becerilerinin ikinci dilde okumaya etkilerinin incelenmesi. The Journal of Academic Social Science Studies, 6(4), 1-19. DOI: http://dx.doi.org/10.9761/JASSS832

Evin Gencel, i. (2013). Öğretmen adaylarının yaşam boyu öğrenme yeterliliklerine yönelik algıları. Eğitim ve Bilim, 38(170), 237-252.

İzci, E. ve Koç, S. (2012). Öğretmen adaylarının yaşam boyu öğrenmeye ilişkin görüşlerinin değerlendirilmesi. Adıyaman Üniversitesi Sosyal Bilimler Enstitüsü Dergisi, 5(9), 101-114. DOI: https://doi.org/10.14520/adyusbd.267

Karasar, N. (2016). Bilimsel araştırma yöntemi: kavramlar, ilkeler, teknikler. Ankara: Nobel Yayıncılık.

Kardaş, N. (2013). Fen eğitiminde argümantasyon odaklı öğretimin öğrencilerin karar verme ve problem çözme becerilerine etkisi (Yayımlanmamış yüksek lisans tezi). Eskişehir Osmangazi Üniversitesi Eğitim Bilimleri Enstitüsü, Eskişehir.

Kavcar, C. (1999). Edebiyat ve eğitim. Ankara: Engin Yayınevi.

MEB. (2018). PISA Türkiye. Erişim Adresi: http://pisa.meb.gov.tr/?page_id=18

MEB. (2019a). Türkçe Dersi Öğretim Programı (ilkokul ve Ortaokul 1,2,3,4,5,6,7 ve 8. sınıflar). Erişim Adresi:https://mufredat.meb.gov.tr/Dosyalar/20195716392253-02-

T\%C3\%BCrk\%C3\%A7e\%20\%C3\%96\%C4\%9Fretim\%20Program\%C4\%B1\%202019.pdf

MEB. (2019b). PISA 2018 Türkiye Ön Raporu. Ankara: Eğitim Analiz ve Değerlendirme Raporları Serisi, 10 Erişim

Adresi: http://yenice17.meb.gov.tr/meb_iys_dosyalar/2019_12/04152229_Pisa_2018_Turkiye_On_ Raporu_2.pdf

Oral, B. ve Yazar, T. (2015). Öğretmen adaylarının yaşam boyu öğrenmeye ilişkin algılarının çeşitli değişkenlere göre incelenmesi. Elektronik Sosyal Bilimler Dergisi, 14(52). 1-11. DOI: https://doi.org/10.17755/esosder.72011 
Özatalay, H. (2007). Ilköğretim I. kademe Türkçe öğretim programında öğrencilere kazandırılması hedeflenen temel becerilerin ders kitaplarında kullanılmasına ilişkin durum çalışması (Yayımlanmamış doktora tezi). Marmara Üniversitesi Eğitim Bilimleri Enstitüsü, İstanbul.

Özdamar, K. (2004). Paket programlar ile istatistiksel veri analizi I. (5. Baskı). Eskişehir: Kaan Kitabevi.

Sever, S. (2001). Öğretim dili olarak Türkçenin sorunları ve öğretme-öğrenme sürecindeki etkili yaklaşımlar. Ankara University Journal of Faculty of Educational Sciences (JFES), 34(1), 11-22. DOI: https://doi.org/10.1501/Egifak_0000000047

Sever, S. (2011). Türkçe öğretimi ve tam öğrenme. Ankara: Anı Yayıncılık.

Tavşancıl, E. (2006). Tutumların ölçülmesi ve SPSS ile veri analizi. Ankara: Nobel Yayın Dağıtım.

Türk Dil Kurumu Sözlüğü. (2019). Dil. Erişim Adresi: https://sozluk.gov.tr/

Türkiye Yeterlilikler Çerçevesi. (2015). Ankara: Mesleki Yeterlilik Kurumu. Erişim Adresi: https://www.myk.gov.tr/images/articles/editor/130116/TYC_teblig_2.pdf

Yaman, H. ve Göçen, G. (2014). Türkiye ve Singapur ana dili öğretimi programları üzerine karşılaştırmalı bir araştırma, Eğitimde Kuram ve Uygulama, 10(4), 783-806.

Yaman, H. ve Dağtaş, A. (2015). Norveç ve Türkiye'deki ana dilli öğretim programlarının karşılaştırmalı olarak analiz edilmesi, Adıyaman Üniversitesi Sosyal Bilimler Enstitüsü Dergisi, 8(19), 343-382. DOI: https://doi.org/10.14520/adyusbd.50937

Yaşlığlu, M. (2017). Sosyal bilimlerde faktör analizi ve geçerlilik: Keşfedici ve doğrulayıcı faktör analizlerinin kullanılması. Istanbul University Journal of the School of Business, 46, 74-85.

Yıldız, D. (2015). Türkiye, Kore, Finlandiya ana dili dersi öğretim programlarının karşılaştırmalı olarak incelenmesi, Eğitim ve Bilim, 4O(179), 89-110. DOI: http://dx.doi.org/10.15390/EB.2015.4166

Yılmaz, M. ve Benli, N. (2010). Sınıf öğretmeni adaylarının okuma alışkanlığına yönelik tutumlarının bazı değişkenlere göre incelenmesi. Erzincan Eğitim Fakültesi Dergisi, 12(1), 281-291.

\section{Introduction}

\section{Extended Abstract}

Ministry of National Education defines the main purpose of education as "raising individuals with knowledge, skills and behaviors that are integrated with our values and competencies". While gaining knowledge, skills and behaviors through curricula, our values and competencies ensure the integrity in these areas (MEB, 2019a).

The national and international competencies that the students will need for personal, social, academic, and vocational life have been determined in Turkish Qualifications Framework (TQF). In 2018, the curricula of all undergraduate courses have been updated and eight key qualifications have been identified for all programs by TQF. The key qualifications are as follows: communication in foreign languages, mathematical competency and basic science/technology competencies, digital competency, learning how to learn, social and citizenship competencies, taking initiative and entrepreneurship, cultural awareness and expression. One of these eight 8 key competencies is "communication competence in the mother tongue" (MEB, 2019a).

Communication in mother tongue means expressing and interpreting concepts, thoughts, opinions, feelings and facts both verbally and in writing (listening, speaking, reading and writing); and interacting linguistically in an appropriate and creative manner in all social and cultural contexts such as education and training, workplace, home and entertainment (MEB, 2019a).

Mother tongue education is the foundation of all disciplines. Students use Turkish, which is their mother tongue, in the learning processes of all primary and secondary schools courses, in Turkey. Students' success at school and in their daily life depends on their ability to learn and use their mother tongue correctly and properly (Yaman \& Dağtaş, 2015). Mother tongue teaching can affect students in two different ways, the first one is that the student improves his/her productive skills by using his / her native language correctly and beautifully. The other is that the student develops his/her personality by gaining maturity of thinking (Açık-Önkaş, 2010).

Raising individuals who have a habit of reading, are considerate and sensitive to their environment is the general purpose of mother tongue teaching. Integrity should be ensured between 
all stages of teaching process from the beginning of primary school until the graduation from the university, and the acquisition of behaviors should be developed gradually (Açık-Önkaş, 2010).

Studies aimed at gaining communication competence in the mother tongue should be included in all levels of education from primary school to university level. Based on this, this study aimed to develop a scale to measure communication competence in the mother tongue and to determine the communication competence of pre-service teachers in their mother tongue.

\section{Method}

The study group consists of 390 prospective teachers studying at Eskişehir Osmangazi University Faculty of Education, Science Education, Mathematics Teaching and Elementary Education departments in the fall semester of 2019-2020 academic year.

"Mother Tongue Communication Competency Scale" was developed and applied as a data collection tool.

Based on the results of the analysis, items with the lowest factor loading value (items 1 and 24) were removed from the scale. The 22 -item scale was finalized after the validity and reliability analysis, with no sub-dimensions.

\section{Result and Discussion}

Within the scope of this study, a 22-item "Mother Tongue Communication Scale" had been developed. The results of the exploratory factor analysis had showed that the scale was a valid and a reliable measurement tool. The Cronbach's Alpha value calculated for the overall scale was found to be 0.857 . This value was considered as an acceptable value in reliability categories. Scale components explained $56,824 \%$ of the total variance. The high level of positive correlation between scale components and with the total score of the scale indicated that the scale had a one-dimensional structure. Considering the results of the analyses, the scale was found to be a useful measurement tool to determine the communication competencies of teacher candidates in the mother tongue.

The mother tongue communication competence of prospective teachers did not show a significant difference according to gender and class variables. A meaningful difference was found in native language communication competencies according to STEM education, argumentation education, satisfaction levels of the departments and the departments the prospective teachers studied. As a result of this research, "Mother Tongue Communication Competency Scale" was determined as a valid and reliable tool for determining the level of communication competence in mother tongue.

\section{Ekler}

\section{Ek-1. Ana Dilde İletişim Yetkinliği Ölçeği}

\begin{tabular}{|c|c|c|c|c|c|}
\hline & 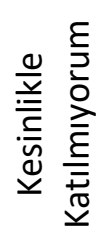 & 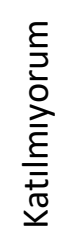 & 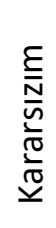 & 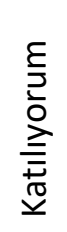 & 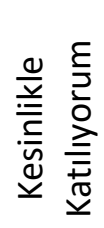 \\
\hline 1. Eğitim konusundaki düşüncelerimi ifade ederim. & & & & & \\
\hline 2. Konuyu ilk okuduğumda anlarım. & & & & & \\
\hline 3. Düşüncelerimi rahatça ifade ederim. & & & & & \\
\hline 4. Okuduğum problemi tek seferde anlarım. & & & & & \\
\hline 5. Arkadaşlarımla iletişimim güçlüdür. & & & & & \\
\hline $\begin{array}{l}\text { 6. Arkadaşlarımla sözlü iletişim kurarken sıkıntı } \\
\text { yaşamam. }\end{array}$ & & & & & \\
\hline 7. Arkadaşlarımla dijital ortamda iletişim kurarım. & & & & & \\
\hline 8. Kendimi yazılı olarak ifade ederim. & & & & & \\
\hline
\end{tabular}




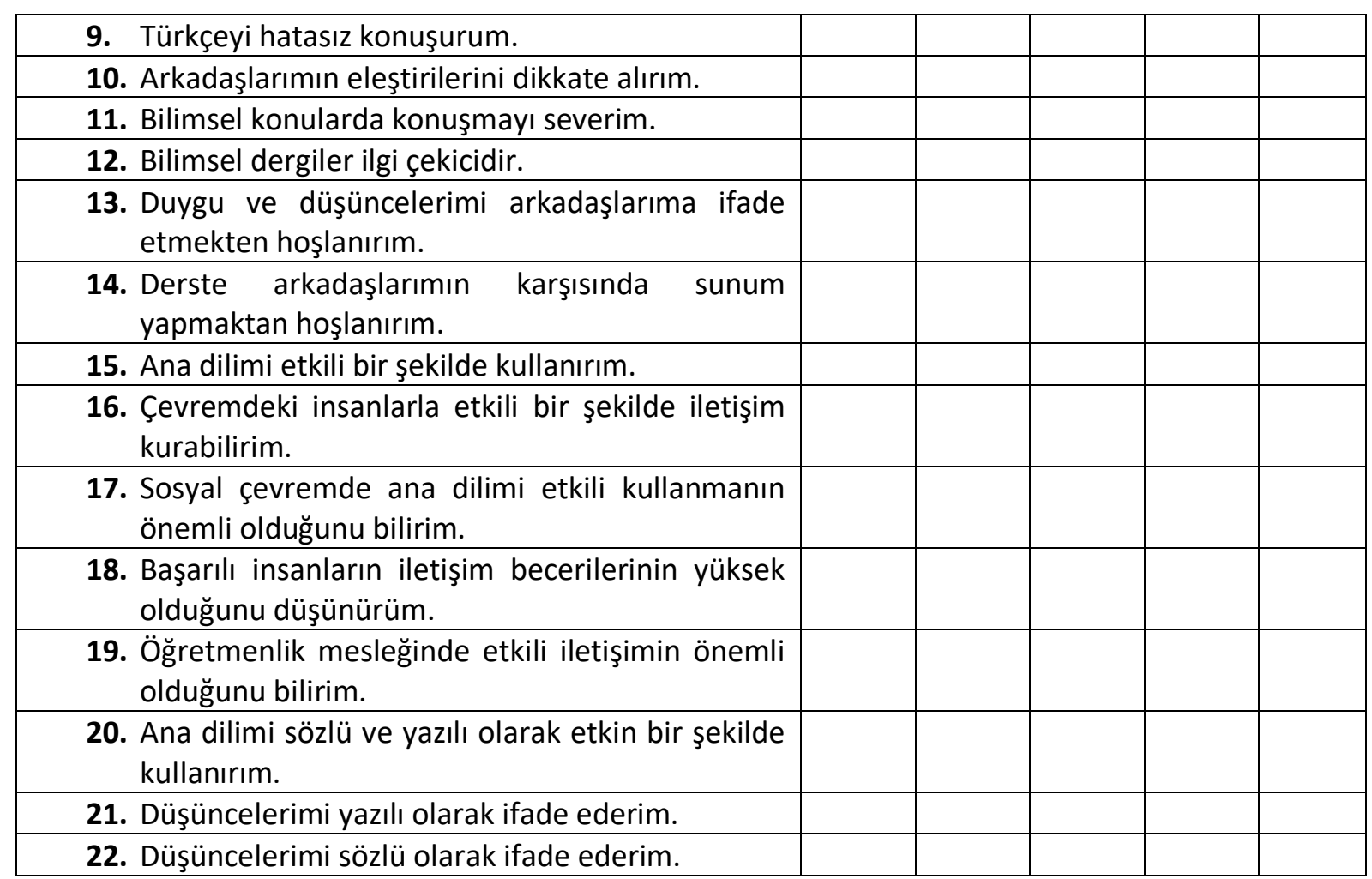

